\section{From Alma-Ata to the Global Fund: the history of international health policy*}

\section{De Alma-Ata ao Fundo Global: a história da política internacional de saúde*}

\author{
Gavino Maciocco ${ }^{1}$ \\ Angelo Stefanini ${ }^{2}$ \\ 1,2 Italian Global Health Watch. Via Berselli 4. Bologna, Italy \\ 1 Dipartimento di Sanità Pubblica, Università di Firenze, Viale \\ Morgagni 48, 50134. Firenze, Italy. \\ E-mail: gavino.maciocco@unifi.it
}

"Global Funds are like stars in the sky, you can see them, admire them, appreciate their abundance... but fail to touch them." Ministry of Health Official, Malawi.

\begin{abstract}
'Verticalization' of health care delivery, in one form or another, is the common theme pervading the history of international health policy over the last sixty years. It is often accompanied by radical policies of privatization of health services, everywhere resulting in people being forced to pay for all services. The failure of the vertical approach, of which the global public-private partnership initiatives are a modernized version, has been well recognized and its reasons are clear: actions on the distal determinants of disease (income, education, housing, the environment and infrastructure, etc) are overlooked; distribution of services dedicated to specific diseases and interventions (such as AIDS, malaria, tuberculosis, etc.) are artificially and temporarily reinforced, creating absurd and harmful forms of competition between services and making even more precarious and inefficient the work of already fragile basic health systems. This article describes the role played in this disturbing historical development by the prevailing economic ideology and its operational arm, the World Bank, with the view to reclaim international policy making processes and actors that really respond to people's health needs.
\end{abstract}

\section{Resumo}

A "verticalização" da assistência à saúde, de uma forma ou de outra, é o tema comum que permeia a história política internacional de saúde ao longo desses últimos sessenta nos, muitas vezes acompanhada com políticas radicais de privatização dos serviços de saúde, resultando, em todos os lugares, na obrigatoriedade de pagamento pelo povo, de todos os serviços. A falência da abordagem vertical, cujas iniciativas de parcerias globais público-privadas constituem sua versão moderna, tem sido reconhecida, tendo sido claras as suas razões: negligenciamento das ações sobre os determinantes distais das doenças (renda, educação, moradia, o ambiente e a infra-estrutura, etc.); a distribuição de serviços dirigidos para doenças específicas e intervenções (tal como AIDS, malária, tuberculose, etc.) é artificial e temporariamente reforçada gerando maneiras perigosas e absurdas de competição entre os serviços e tornando o trabalho já frágil dos sistemas de saúde ainda mais precário e ineficiente. Esse artigo descreve o papel exercido neste desenvolvimento histórico perturbador ocasionando pela ideologia econômica predominante e seu braço operacional, o Banco Mundial, com o objetivo de reclamar que o processo de decisão política internacional e seus atores realmente respondam pelas necessidades de saúde do povo.

\footnotetext{
*Invited contribution for the Global Theme Issue on Poverty and Human Development organized by the Council of Science Editors.
} 
More than sixty years after the adoption of the Constitution of the World Health Organization (WHO) aiming at "the attainment by all people of the highest possible level of health", many people in poor countries still do not have access to basic healthcare services. Moreover, while standards of living in many developing countries is improving, an increasing gap is opening up between the health of the rich and the poor.

This article describes the role played by the prevailing economic ideology and its operational arm, the World Bank with the view to reclaim international policy making processes and actors that really respond to people's health needs. It is divided in two sections: the rise and fall of World Health Organization's health for all strategy, and the evolving of the Global Fund (GF) as the instrument of a radically new approach to health financing and health policy making in the poorest countries.

\section{The World Health Organization: its rise and fall}

The World Health Organization was formally established in June 1948 as a specialized agency of the United Nations. ${ }^{1}$ During the 1960's and 70's its direction was influenced by political events related to the emergence from decolonization of African nations, of nationalist and socialist movements and the new theories of long term socioeconomic growth as opposed to short term technical interventions. The International Conference on Primary Health Care (PHC) convened by WHO and United Nations Children's Fund (UNICEF) in Alma Ata (Kazakhstan) in 1978 and attended for the first time by representatives from all countries in the world, generated a solemn Declaration ${ }^{2}$ that strongly emphasized: a) health as a basic human right; b) the role of the state in the universal provision of health care; c) community participation as a fundamental prerequisite for effective health care.

Several reasons concurred to make Alma Ata, under the WHO's leadership of its Director General, Hafdan Mahler, an historic event. It was the first time that the health care problems of the poorest countries were seriously taken into consideration. Secondly, both health needs and development issues were strongly linked. In addition, access to the highest level of health was seen as an extremely important social objective of global interest that presupposes the participation of numerous social and economic sectors, not only the health sector. ${ }^{3}$

Less than a year after the solemn Declaration, its "comprehensive" approach to health was strongly challenged for its alleged vagueness and high costs. ${ }^{4}$ A more cost-effective strategy (named Selective PHC-SPHC), focused on medical interventions (such as vaccinations, promoting longer breast feeding, oral rehydration and monitoring child health growth) was proposed. ${ }^{5}$ From that moment on, international organizations adopted SPHC as their strategy even though confronted with all the evidence that the determinants of progress and improved health in any population go well beyond the fighting against only one or two diseases. ${ }^{6}$ It appeared clear that politicians and the medical establishment could not accept the core PHC principle that communities would have responsibilities to plan and implement their own health services. ${ }^{7}$ According to the late Professor K.W. Newell, from the Liverpool School of Tropical Medicine:

Selective PHC is a threat and must be considered as a counter-revolution. It is a form of health feudalism that is destructive rather than an alternative. Attractive to professionals, financing agencies and governments that are seeking results in the short term, but a pure illusion. (Newell; 1988: 903-6). ${ }^{8}$

The petrol crisis of the 1970 s and 1980s triggered a period of grave recession. Cheap money, borrowed by fast developing, newly independent nations during the early 1970 s, could not be repaid back and the debt crisis exploded. The recipe devised by the World Bank, the International Monetary Fund (IMF) and the US Finance Ministry (the so called "Washington Consensus") for "recovery" or "structural adjustment" of the poorest and most indebted countries (and the contractual conditions for obtaining credit) were simple, pitiless and coherent with the neo-liberal policies dominant in the USA and Great Britain in that period: a) drastic cuts in public spending (including social services such as health and education); b) privatization in all sectors; c) decentralization; d) lower profiles of central governments.

Little consideration was given to the easily predictable catastrophic effects of degrading levels of education and health care (adding to the newly developing tragedy of HIV/AIDS epidemic) on the fundamental basis of development in those countries. In 1987 the World Bank published its first document entirely dedicated to health ${ }^{9}$ a technical appendix to the structural adjustment policy. It contained a series of prescriptions, obviously mandatory for the most indebted countries, for restructuring health services in developing countries, i.e. enforce fee payment for health services, 
encourage the privatization of health services, promote (private) insurance programmes, and decentralize the management of health care. Quite soon the effects of structural adjustment policies were dramatically evident and denounced by UNICEF as "inhuman, unnecessary, inefficient". ${ }^{10}$

The election in 1988 of Hiroshi Nakajima as Director General of the WHO marked the beginning of a decade of institution's crisis only partially linked to the new Director's low profile. ${ }^{11-13}$ A frozen budget and the conflict with the USA were a legacy of the previous administration that dared promoting the International Code on Breast Milk Substitutes (a move seen as an attack to the free market) and the Essential Drugs Programme (fiercely opposed by the pharmaceutical industry). In addition, programme financing through extra-budgetary funding increased while WHO's ordinary budget, that is the budget set by country representatives at the World Health Assembly, was progressively reducing, thus undermining the Organization's institutional role. This meant that various donors, namely the richest nations and multi-lateral agencies such as the World Bank, gradually increased their decisional power in the Organization. In the early nineties the extrabudgetary funds, that represented $54 \%$ of the entire WHO's budget, generated "vertical" programmes (such as AIDS and universal coverage of vaccinations) where decisions were made by the donors and so out of the Organization's control.

The World Bank 1993 annual report, Investing in Health, ${ }^{14}$ made a spectacular entrance for the Bank as the major financial institution in the health scene, further obscuring the already discredited role of WHO. ${ }^{15}$ The report addressed two important technical themes: a) the definition (and economic estimate) of the package of essential health services that governments should assure to their entire population; b) the use of a new indicator of a country's health, the Disability Adjusted Life Years (DALY), to measure the cost of disease interventions and define priorities to allocate resources. ${ }^{16}$

This type of selective approach to PHC provided further grist to the mill confirming the hostility of the World Bank to the principles of Alma Ata. A flood of privatizations occurred within already crumbling public structures, but above all outside, where the private health care market was thriving, a market based largely on the sale of pharmaceuticals, available everywhere, in private clinics, in drug stores, on market stalls, and street corners where medicines are often out of date or counterfeit, almost always distributed by unregistered people. The motives of this drugs boom was soon clear: the lack of access to the formal but too expensive private services (hospitals, health centers, public and private non profit and private for profit, all by payment) forced the vast majority of the population to turn to whoever was able to provide care for the few coins people had in their pocket. The most simple care: a pill or an injection.

The major consequences produced by World Bank health policies in the poorest countries are denounced in a Lancet oft-quoted article:

The 'global model' of health systems as supported by the WB ... [i.e.] the introduction of user fees in public services and the growing out of pocket expenses in private services, if combined, represent a true poverty trap. (Whitehead et al.; 2001: 833-6). ${ }^{17}$

This leads to untreated diseases, reduced access to care, irrational use of drugs, and long term impoverishment.

\section{Public-private-partnerships and the Global Fund}

In spite of important initiatives (such as the institution of the Macroeconomics and Health Commission, and the adoption by the WHO Assembly of the "WHO Framework Convention on Tobacco Control"), the policy of the new Director General (GR) Harlem Bruntland, was not significantly different from the World Bank's. During her direction (1998 to 2003) there was a proliferation of activities financed by extra-budgetary mechanisms which soon outnumbered those funded by the WHO regular budget ( $\$ 1.400$ million opposed to $\$ 800$ million in 2002). ${ }^{18}$ A consequence of the World Bank's policy to withdraw governments from the health sector and increase support to privatization was the emergence of public-private ventures (public private partnerships-PPP), both at local and global level, supposedly injecting the virtues of private entrepreneurship into public institutions and programmes. One of the most prominent of these ventures was the Global Alliance for Vaccines and Immunization (GAVI), where WHO had a very marginal role that in September 2002 received $\$ 750$ million out of a donation of $\$ 2.8$ billion to similar initiatives by the Bill and Melinda Gates Foundation.

In June 2001, a special session of the United Nations General Assembly addressed the fact that in sub-Saharan Africa less than 40.000 people were receiving antiretroviral treatment in an area where 25 million were infected or ill and 2.2 million died each year by HIV/AIDS. The session's final docu- 
ment indicated \$7-10 billion as the annual amount the international community should allocate to adequately tackle the "global crisis", through a Special Fund for HIV/AIDS open to governments, the private sector, foundations and individuals in a "new partnership". Several weeks later, the concluding meeting of the Genoa G8 summit approved the creation of the "GF to Fight AIDS, Tuberculosis and Malaria" (GF) then formally instituted on the $29^{\text {th }}$ of January 2002 in Geneva". Its aim was to attract, manage and allocate added resources through a new private public partnership providing a significant and sustainable contribution to the reduction of the infection, illness and mortality caused by HIV/AIDS, tuberculosis e malaria, mitigating their impact on needy countries and aiding poverty reduction as part of the "Millennium Development Objectives". ${ }^{18}$

The GF is a financing agency and not an implementing or project managing entity. It receives funds from public donors (93\% from governments) as well as private, mainly Bill Gates (7\%), and allocates funds to projects developed locally by public and private organizations. At the national level, project selection takes place through the Country Coordinating Mechanisms (CCM), a collegial body made up of representatives from governments, universities, bilateral and multilateral institutions, NGOs, private organizations and patients. At the central level, project evaluation is carried out by a group of experts, the Technical Review Panel (TRP), whose recommendations are used by the GF Board in their decisions on project feasibility. The GF Board is made up of representatives from donor and receiving countries, NGOs, private organizations and affected communities. There are 20 members plus non voting representatives from multilateral institutions, WHO, UNAIDS and the World Bank (which acts as the GF bank). Project proposals are called for on annual basis. Round 7 of the GF opened on the $1^{\circ}$ March 2007.

\section{The Global Fund scorecard}

The most recent GF document from February 2007, Partners in impact. Result report, provides the following data. On 31 December 2006, from the moment of its institution, the GF had signed agreements and funding commitments for a total of $\$ 5.3$ billion, for 410 projects in 132 countries. Overall, in more than three years, the GF allocated $\$ 3.5$ billion. On the 1st of December 2006, 770.000 people were undergoing antiretroviral treatment, 2 million were in Directly Observed Therapy (DOTS) treatment against tuberculosis, 18 million mosquito nets treated with insecticides had been distributed to protect families from malaria (Figure 1). As a consequence of these results, the GF report claims that by the $31^{\text {st }}$ of January 2007, 1.460 .000 lives had been saved (3000 a day). The breakdown of funds for the three illnesses was the following: 56\% for AIDS, $28 \%$ for malaria and $16 \%$ for tuberculosis. GF funds went to governments (59\%), NGOs (30\%), multilateral agencies $(9 \%)$, and privates $(2 \%)$, and covered the following sectors: prevention (33\%), treatment (44\%), assistance and support (7\%), administration $(7 \%)$, strengthening of health system $(6 \%)$, monitoring and evaluation $(1 \%)$, other $(2 \%)$. Does the GF work? How can these results be evaluated in terms of resources spent (input), services delivered (output) and the health results achieved (outcome)? In attempting to answer these questions we will look particularly at HIV/AIDS, the condition which has absorbed most of the GF funds.

INPUT. The financial objective recommended in the final document of the special United Nations Assembly in June 2001 for the campaign against AIDS was \$ 7-10 billion per year. Thus the funds effectively spent by the GF were on average slightly more than $\$ 1$ billion per year for the three illnesses. Of these, about $\$ 600$ million were spent on AIDS. As is shown in Figure 2 the GF only contributed $21 \%$ of the total AIDS funds, that is around \$3 billion per year (less than half the objective set by the United Nations). Moreover Figure 3 shows that in recent years there has not been a significant increase in funds pro capita in the campaign against Aids throughout the world, with only Sub-Saharan African countries registering a slight but constant increase. ( $+\$ 1 / 2$ per capita in four years).

OUTPUT. In September 2003 the WHO Director General, Lee Jong-Wook, the UNAIDS Director General, Peter Piot, and the Executive Director of GF, Richard Feacham, declared that such a low level of cover with antiretroviral drugs was not acceptable in countries with low and medium levels of development and that it was necessary to launch a powerful campaign to rapidly lessen the gap. It was called "3 by 5 ", aiming to treat 3 million people by 2005 , or in other words reach $50 \%$ of the population eligible for treatment. The results of the " 3 by 5 " were disappointing. At the end of 2005 according to UNAIDS data, only 1.300 .000 people were in treatment $(43 \%$ of the target, $20 \%$ of the eligible population). The coverage achieved was the result of multiple initiatives leading to a situation where the sum of the levels of coverage claimed by the various actors was 
Increases in ARV, DOTS and ITN; results sine December 2004, showing targets set for the Global Fund with its board (dotted lines).

RAPID GROWTH IN ARV, DOTS AND ITN RESULTS

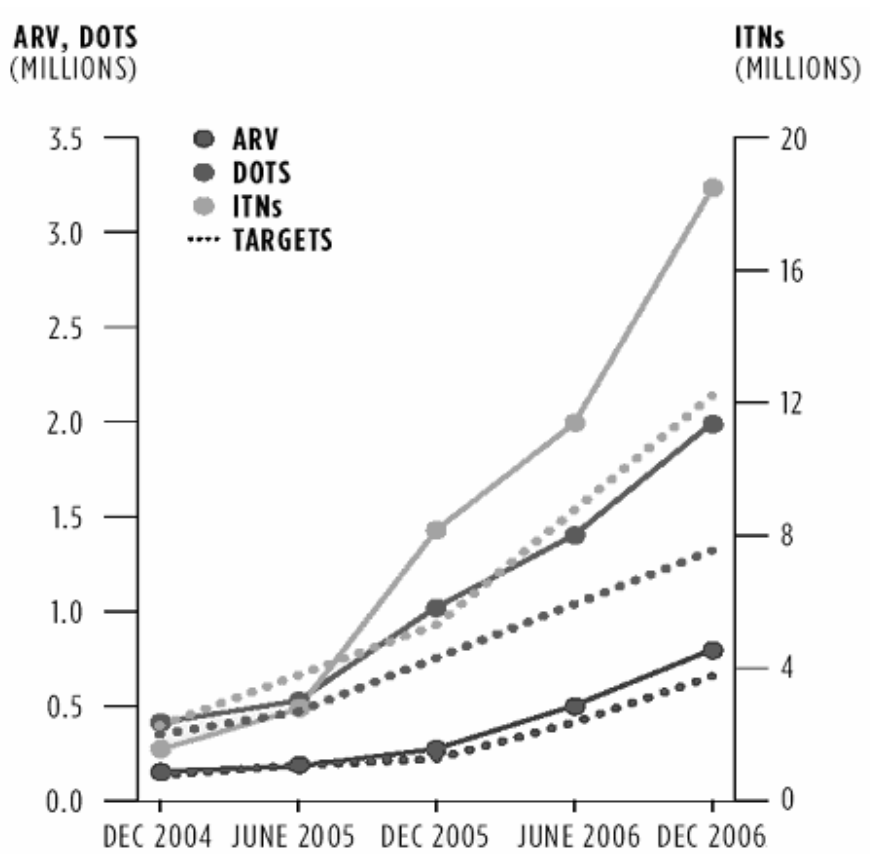

Source: The Global Fund.

\section{Figura 2}

Financing of HIV/AIDS programmes.

HIV/AIDS

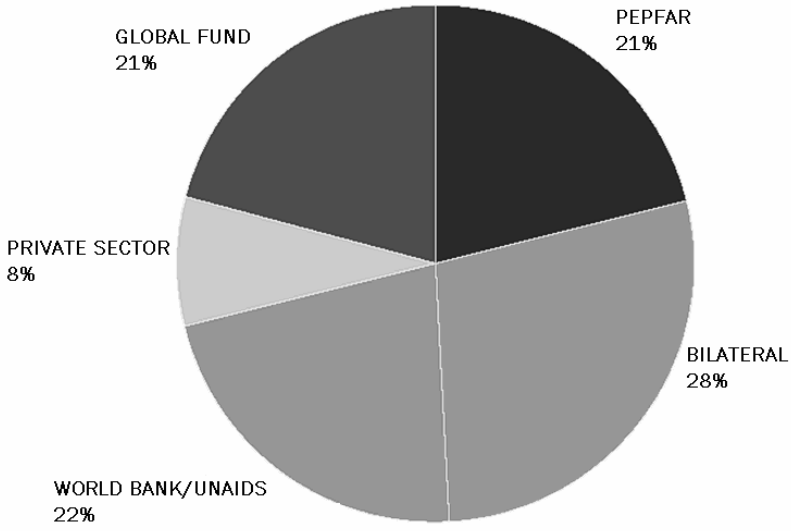


Per capita HIV and AIDS expenditures by country income level.*

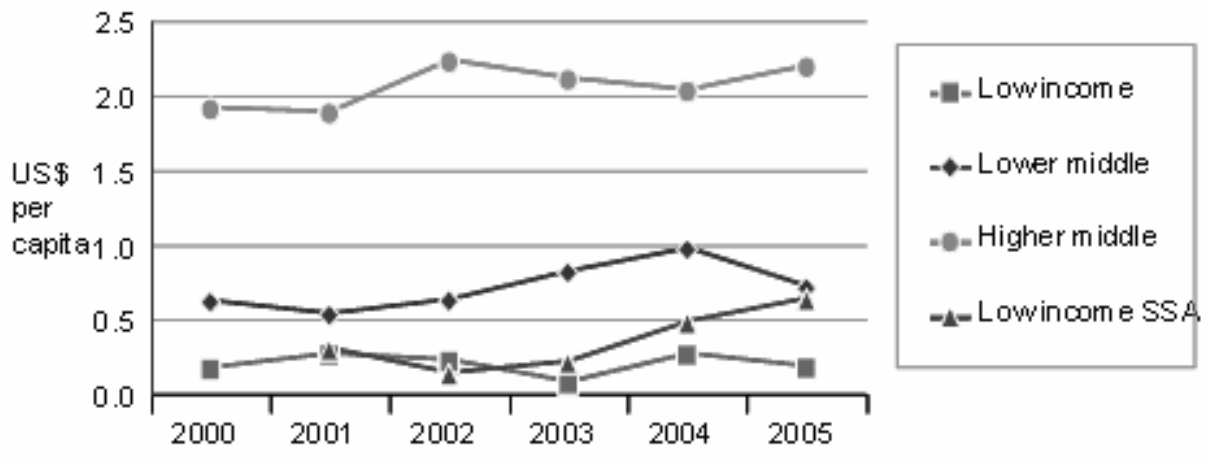

* Trends based on a sample of 25 countrie srom sub-Saharan A frica and 57 countries from other regions

Maternal mortality (deaths per 100.000 live births) in the African Region.

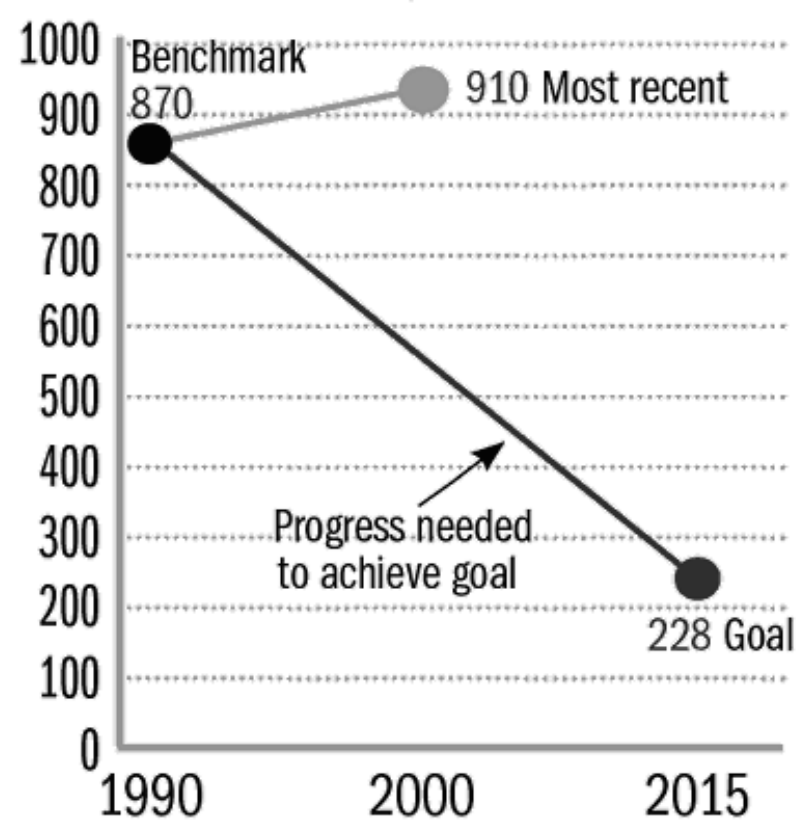

Source: Based on data from: WHO (World Health Organization). The world health report: 2005. Geneva; 2005. greater than that certified by UNAIDS. To the 770.000 people in treatment at the end of 2006 cited by GF we must add PEPFAR (President's (Bush) Emergency Plan for AIDS Relief - www.pepfar.gov) with 822.000; CHAI (Clinton Foundation HIV/AIDS Initiative-www.clintonfoundation.org) with 415.000; the many foundations of Bill Gates (65.000 in Botswana). Deciphering the data on the levels of antiretroviral treatment is extremely difficult as an analysis of the UNAIDS document shows with strongly contrasting data from different sources.

OUTCOME. The GF claims one and a half million lives saved at a rate of 3.000 per day. Although these figures are acceptable, outcome evaluation is much more complex. The opportunity cost of the GF must be taken into consideration, i.e. what other alternatives had been forfeited in adopting the GF strategy. Thus, although the GF achieved several health objectives in the area of HIV/AIDS, tuberculosis and malaria, in the same period in Africa there was a decline in health standards in the maternal and child sector (Figure 4), which is the most accurate index of the general functioning of a health system in terms of access and quality of services and personnel. This decline could also be a direct result of the GF policy and mechanisms such as the competitive recruitment of its own staff and consequent neglect of other activities such as pre-natal programmes and infant assistance (not included in special funds or vertical programmes). 


\section{Global Fund's main weaknesses}

The GF came into existence when there were already specific public private partnerships (PPPs) for each of the areas concerned (AIDS, tuberculosis and malaria) such as UNAIDS, Roll Back Malaria, Stop Tuberculosis. Although many PPP actors are omnipresent, this is often not sufficient in itself and they set up actions and autonomous finances within the same sectors (eg. G. W. Bush's PEPFAR) leading to a surplus of actors and protagonists at all levels, finance, programming, management, field work, evaluation. This situation was subject to a concerned report by UNAIDS in $2005,{ }^{19}$ which noted that a significant increase in available finances was accompanied by a serious lack of co-ordination in fund management and organization producing duplication and competition between various sponsors and provoking what the UNAIDS defined as "the implementation crisis", caused by unsustainable organizations and extremely high administrative costs. A recent Lancet ${ }^{20}$ editorial focuses on a paradoxical aspect of this disorganization, caused by the verticalization of services. The co-existence of HIV/AIDS and tuberculosis is compounding the problem, involving about 11 million patients who are also those with the greatest concentration of resistance to antituberculosis drugs. Although it is crucial that patients suffering from the two diseases be treated by the same service and health workers, the reality is that two programmes (AIDS e Tuberculosis) operate separately causing enormous problems for patients.

A second weakness is pinpointed in a recent document by the IMF (i.e. the same institution that, in pair with the World Bank, enthusiastically promotes the selective, vertical approach) that states:

Perversely, the large inflows of donor assistance targeted to these diseases (through so-called vertical disease programs) have weakened the infrastructure and drained the human resources required for preventing and treating common diseases (such as diarrhea, and upper respiratory infections) that may kill many more people. Furthermore, multiple donors, each with their own priorities, bureaucratic requirements, and supervisory structures, have created waste and confusion with recipient nations. Lastly, an important concern is the sustainability of these vertical programs, since donors' funds may not prove stable or longlasting. For recipient countries, these inflows have created difficult challenges in the management of the health sector. (Hsiao, Heller; 2007: 8). ${ }^{21}$

Round 5 (2005) for proposals to the GF permitted for the first time the submission of projects oriented towards the strengthening of health systems. ${ }^{22}$ The GF's Executive Director, Richard G.
Feacham, has spoken on the question of the "vertical programming versus strengthening the health systems" 23 suggesting a new role for the GF as the institution in charge for rapid intervention on specific diseases, and for the World Bank that would be responsible for developing a strategy of long term change in health systems. ${ }^{23}$ That is to say, the World Bank as the "global super health ministry", a role that the Bank has de facto carried out in the last two decades.

\section{Conclusions}

The history of the international health policy over the last 60 years mirrors the debate between two profoundly different visions of health and how to promote it. The core argument focuses, today as half century ago, on the interrelationships between health and socio-economic development. Whereas the conservative medical establishment, supported by the international financial institutions, has been arguing for fighting disease through cost-effective technical interventions (i.e. selective, vertical programmes and GPPPs), the genuine PHC approach, as envisioned at Alma Ata, has strong political implications, addresses social, economic and political causes of poor health and emphasizes universal accessibility and coverage on the basis of need. $^{24}$

"The failure of the vertical approach has been well recognized: the fundamental indicators of health in the poorest countries (life expectation at birth, infant and maternal mortality) have remained stationary or even worsened... The reasons for failure are clear. Actions on the distal determinants of disease (income, education, housing, the environment and infrastructure, etc) are overlooked. Furthermore, inequity between countries and within communities in countries has grown, also due to unfair global commence. Vertical programmes have artificially and temporarily reinforced distribution of services dedicated to specific diseases and interventions (AIDS, malaria, tuberculosis, etc.), creating absurd and harmful forms of competition between services (e.g. local personnel migrating to more financially attractive agencies) making even more precarious and inefficient the work of already fragile basic health systems. 'Verticalization' accompanied by radical policies of privatization of health services everywhere resulting in people being forced to pay for all services. This creates barriers to access to care especially for populations already 'trapped in poverty', as expenditure on medical care is a critical burden that impoverishes families). ${ }^{25}$ 
In conclusion, the GF is not a casual initiative, nor is it the fruit of an improvised political event (G8 Genoa). It is the direct consequence of a chain of circumstances and political choices that reflect the history of international health institutions and organizations. International health cooperation must be held accountable in addressing this challenge in view of

\section{References}

1. WHO (World Health Organization). Constitution of the World Health Organization. Geneva; 1946.

2. WHO (World Health Organization), UNICEF (United Nations Children's Fund). Alma-Ata 1978: Primary Health Care. Geneva; 1978. (Series n. 1: Health for All).

3. Brown TM, Cueto M, Fee E. The World Health Organization and the transition from International to Global Public Health. Am J Public Health. 2000; 96: 62-72.

4. Walsh JA, Warren KS. Selective primary health care: an interim strategy for disease control in developing countries. New Engl J Med. 1979; 301: 967-73.

5. Grant JP. The state of the world's children, 1982-83. Oxford: Oxford University Press, UNICEF; 1982.

6. Halstead SB, Walsh JA, Warren KS, editors. Conference summary statement. In "Good Health at Low Cost" New York; The Rockefeller Foundation; 1985; apud Warren KS. The evolution of selective primary health care. Soc Sci Med. 1988; 26: 891-8.

7. Green A. An introduction to health planning in developing countries. Oxford: Oxford Medical Publications; 1999.

8. Newell KW. Selective primary health care: the counter revolution. Soc Sci Med. 1988; 26: 903-6.

9. World Bank. Financing health services in developing countries: an agenda for reforms. Washington, DC; 1987.

10. Grant JP. The state of the world's children, 1989. Oxford: Oxford University Press, UNICEF; 1989.

11. Godlee F. The World Health Organization: WHO in crisis. Br Med J. 1994; 309: 1424-8.

12. Godlee F. WHO in retreat: it is losing its influence? Br Med J. 1994; 309: 1491-5.

13. Godlee F. The World Health Organization: WHO's special programmes: undermining from above. Br Med J. 1995; 310: 178-82.

14. World Bank. World development report 1993: investing in health. Washington, DC; 1993.

15. Buse K, Walt G. Role conflict? The World Bank and the world's health. Soc Sci Med. 2000; 50: 177-9.

16. Murray CJL. Acharya AK. Understanding DALYs. J Health Econom. 1997; 16: 703-30.

17. Whithead M, Dahlgren G, Evans T. Equity and health sector reforms: can low-income countries escape the medical poverty trap? Lancet. 2001; 358: 833-6. the millions of deaths (among which more than 10 million young children and 500.000 women during pregnancy and birth) from conditions that could be easily preventable or curable through universal access to effective, quality basic health care services, food, clean water and education. ${ }^{26}$
18. The following programmes were promoted and financed by public and private partners (PPP): European Partnership Project on Tobacco Dependence, Global Alliance for TB Drug Development, Global Alliance to Eliminate Lymphatic Filariasis, Global Alliance to Eliminate Leprosy, Global Alliance for Vaccines and Immunization, Global Elimination of Blinding Trachoma, Global Fire Fighting Partnership, Global Partnerships for Healthy Aging, Global Polio Eradication Initiative, Global School Health Initiative, Multilateral Initiative on Malaria, Medicines for Malaria Venture, Partnership for Parasite Control, Roll Back Malaria, Stop TB, UNAIDS/Industry Drug Access Initiative.http://www.theglobalfund.org [2007 March 15].

19. UNAIDS. The Joint United Nations Programme on HIV/AIDS. Technical support division of labour: August 2005. Available from: www.unaids.org [2007 March 15]

20. Stopping tuberculosis proves hard to do [editorial]. Lancet. 2007; 369: 965.

21. Hsiao W, Heller PS. What should macroeconomists know about health care policy? Washington: IMF-International Monetary Fund; 2007. (Working Paper, WP/07/13).

22. Feacham RG. An examination of the Global Fund at five years. Lancet. 2006; 368: 537-40.

23. Shakow A. Global Fund-World Bank HIV/AIDS programmes: comparative advantage study. 2006. Available from: www.theglobalfund.org [2007 March 7].

24. Sanders D. Twenty-five years of PHC: lessons learned and proposal for revitalization. University of Western cape, South Africa, 2003. Available from: www.asksource.info/phc-sanders.RTF [2004 February 20].

25. Italian Global Health Watch. Document submitted to the Italian Governmen: September 2006.

26. Stiglitz J. Quanto pagano i paesi poveri per l'egoismo dell'Occidente. [How much do poor countries pay for the egotism of the West] La Repubblica. 2002 Aug 18: 26.

Received on September 12, 2007

Final version on October 15, 2007 